УДК 615.014.07:615.451.16:582.635.3:547.466

DOI https://doi.org/10.11603/2312-0967.2021.1.11981

\title{
ВИВЧЕННЯ АМІНОКИСЛОТНОГО ПРОФІЛЮ СИРОВИНИ ЛИСТЯ ШОВКОВИЦІ БІЛОЇ ТА СУХОГО ЕКСТРАКТУ НА ЙОГО ОСНОВІ
}

\author{
Л. В. Вронська \\ Тернопільський національний медичний університет імені І. Я. Горбачевського мОЗ \\ України \\ vronska_liudmyla@ukr.net
}

ІНФОРМАЦІЯ

Надійшла до редакції / Received: 25.01.2021

Після доопрацювання / Revised: 09.02.2021

Прийнято до друку / Accepted: 11.02.2021

\section{Ключові слова:}

листя шовковиці білої;

сухий екстракт;

амінокислоти.

\section{АНОТАЦІЯ}

Мета роботи. Вивчення амінокислотного профрілю листя шовковиці білої й сухого екстракту на його основі.

Матеріали і методи. Чотири зразки сировини листя шовковиці білої були зібрані у Волинській, Миколаївській і Тернопільській областях, один зразок був придбаний як дієтична добавка «Morwa biała» (APTEO NATURA, Польща). Сухий екстракт листя шовковиці білої отримували із сировини вітчизняного походження методом дробної мацерації, застосовуючи етанол (80-60%, об/об). Дослідження якісного і кількісного складу сировини листя шовковиці білої та екстракту на його основі здійснювали методом високоесективної рідинної хроматографії.

Результати й обговорення. Амінокислотні профрілі чотирьох досліджених зразків сировини вітчизняного походження $€$ однаковими за складом і достатньо однорідними за вмістом. Профріль листя шовковиці білої містить 14 амінокислот у вільному стані для сировини і 13 - для сухого екстракту, з яких незамінних і частково незамінних - 7 і 2 для сировини та 5 і 2 - для екстракту. Визначено вміст амінокислот у вільному стані для різних зразків сировини у межах 0,48-0,70 \% і сухого екстракту - 0,72 \%; за вмістом лідерами у сировині були: глутамінова кислота, пролін, аспарагінова кислота, валін й аланін, тоді як в екстракті - аргінін, пролін, глутамінова кислота, валін, аспарагінова кислота. Профріль зв'язаних амінокислот у сировині представлений 16 сполуками, серед яких лідерами за вмістом були: гліцин, лейцин, аргінін, глутамінова та аспарагінова кислоти, аланін і френілаланін. Загальний вміст вільних і зв'язаних амінокислот у сировині вітчизняного походження (4,09-4,67 \%) дещо поступався їхньому вмістові в аптечному зразкові дієтичної добавки - 5,22 \%.

Висновки. 1. Методом ВЕРХ вивчено амінокислотні профрілі п'яти зразків листя шовковиці білої. Встановлено, що склад є достатньо однорідним, а загальний вміст коливається в межах 4,09-4,67 \%.

2. 13 амінокислот, які перебувають у вільному стані, 3 яких 5 - незамінні та 2 - частково незамінні, ідентиоріковано у сухому екстракті листя шовковиці білої. Визначено вміст вільних амінокислот в екстракті - 0,72 \% і загальний вміст вільних та зв'язаних амінокислот - 1,99 \%.

3. При дослідженні стабільності, встановленні умов зберігання та терміну придатності сировини і сухого екстракту листя шовковиці білої необхідно враховувати присутність вільних і зв'язаних амінокислот.

ISSN 2312-0967. Фармацевтичний часопис. 2021. № 1 
Вступ. Листя шовковиці білої $€$ перспективною рослинною сировиною для створення на його основі засобів, які можуть застосовуватися при легких фрормах цукрового діабету для лікування і профрілактики ускладнень, завдяки антиоксидантній, цукрознижувальній і гіполіпідемічній дії [1-8]. Дослідженню різних класів біологічно активних речовин (БАР) й біологічної дії цієї сировини та її екстрактів присвячено багато оригінальних робіт та оглядів [1-12]. Проте щодо амінокислотного складу листя шовковиці білої наукової інфрормації $€$ недостатньо [10, 13], а даних щодо складу і вмісту амінокислот в екстракті листя шовковиці не виявлено зовсім. Разом з тим, амінокислоти - сполуки 3 важливим біохімічним значенням, вони відіграють головну роль у метаболізмі білків, а в рослинному світі $є$ біогенетичним прекурсором алкалоїдів.

Раніше було отримано сухий екстракт листя шовковиці білої, досліджено його фенольний склад і цукрознижувальну дію [12]. Проте при стандартизації екстракту важливим $€$ вивчення різних класів БАР, які і самостійно, і в комплексі з іншими БАР зумовлюють біологічну дію. Вивчення складу БАР екстракту $€$ важливим для дослідження його стабільності і напрацювання терміну придатності та умов зберігання.

Тому метою роботи було вивчення амінокислотного профрілю листя шовковиці білої й екстракту на його основі.

Матеріали і методи. Сировина листя шовковиці білої була заготовлена в Україні і придбана в аптеці. Заготовлені зразки: 1 - у Миколаївській області, 2 і 4 - у Волинській області, 3 - у Тернопільській області. Листя шовковиці білої, промарковане як зразок 5, було придбане як дієтична добавка «Morwa biała» (APTEO NATURA, Польща). Сухий екстракт листя шовковиці білої отримували із сировини вітчизняного походження методом дробної мацерації, застосовуючи етанол (80-60\%, об/об).

Для вивчення амінокислотного профрілю 5 зразків листя шовковиці білої і екстракту на його основі було застосовано метод високоефективної рідинної хроматографії (BEPX). Дослідження складу і вмісту амінокислот виконували, застосовуючи хроматографр Agilent 1200 («Agilent technologies», США) 3 фрлуоресцентним детектором G1315A («Agilent technologies», США) і автосамплером 1313A («Agilent technologies», США).

Підготовку проб для дослідження вільних амінокислот здійснювали у герметично закритій віалі при температурі $50{ }^{\circ} \mathrm{C}$ в ультразвуковій бані впродовж 3 год шляхом обробки наважки сировини $(0,16$ г) або екстракту (0,16 г) 4,0 мл 0,1 моль/л розчину хлоридної кислоти. Вільні і зв'язані амінокислоти вилучали згідно з методикою: 15 мг сировини або екстракту поміщали у віалу, додавали 0,5 мл 6 моль/л розчину хлоридної кислоти, герметично закривали, і залишали у термостаті на 24 год при $110^{\circ} \mathrm{C}$ для гідролізу; охолоджений гідролізат розводили водою для хроматографії до 4,0 мл.

0,5 мл кожного отриманого вилучення випарювали на роторному випарювачі до сухого при температурі 50 으, додавали 0,5 мл води для хроматографії і знову випарювали, операцію повторювали ще двічі, щоб видалити хлоридну кислоту. Сухий залишок розчиняли при перемішуванні в 0,5 мл води для хроматографії та фрільтрували через шприцеві мікрофрільтри 3 регенерованої целюлози із розміром пор 0,22 мкм. Отриманий фрільтрат поміщали у вставку віали, а останню - в автосамплер.

Дериватизацію амінокислот проводили в автоматизованому онлайн-режимі автосамплера згідно 3 методикою, описаною в [14], використовуючи о-срталевого альдегіду реагент (OPA, Agilent 50613335) для первинних амінокислот, 9-срлуоренілметилхлорформіату реагент (FMOC, Agilent 5061-3335) для вторинних амінокислот. Для ідентифікації амінокислот і побудови градуювальник залежностей застосовували розчини стандартних зразків амінокислот (PN 5061-3334, PN 5062-2478, «Agilent technologies», США), які готували шляхом розчинення і розбавлення суміші стандартів.

Умови хроматографрування описані детально в [14]:

Колонка: Zorbax Eclipse AAA 4,6x150 мм (3 мкм).

Температура колонки: $40^{\circ} \mathrm{C}$.

Рухома фраза А: 40 ммоль/л розчин натрій гідрогеноросорату 3 pH 7,8 (5,5 г натрій гідрогеноросфату моногідрату розчиняли в 1 л води для хроматографії, доводили розчином 10 моль/л натрій гідроксиду до $\mathrm{pH} \mathrm{7,8).}$

Рухома фраза B: ацетонітрил - метанол - вода (45:45:10, об/об /об).

Швидкість рухомої фрази: 1,5 мл/хв.

Градієнт: згідно з програмою

$\begin{array}{ccc}\text { Час, хв } & \text { Рухома фраза А, \% } & \text { Рухома фраза В, \% } \\ 0-1,9 & 100 & 0 \\ 1,9-18,1 & 100 \rightarrow 43 & 0 \rightarrow 57 \\ 18,1-18,6 & 43 \rightarrow 0 & 57 \rightarrow 100 \\ 18,6-22,3 & 0 & 100 \\ 22,3-23,2 & 0 \rightarrow 100 & 100 \rightarrow 0 \\ 23,2-26,0 & 100 & 0\end{array}$

Детектування: фрлуоресцентний детектор згідно з програмою: до 15 хв - довжина хвилі збудження 340 нм, довжина хвилі випромінювання 450 нм; після 15 хв - довжина хвилі збудження 266 нм, довжина хвилі випромінювання 305 нм.

Інжекція: 0,5 мкл.

\section{Результати й обговорення}

В описаних умовах хроматографування і дериватизації були отримані хроматографрічні профрілі вільних і загальних амінокислот. Приклади отриманих хроматограм наведено на рисунках 1-3.

ISSN 2312-0967. Pharmaceutical review. 2021. № 1 


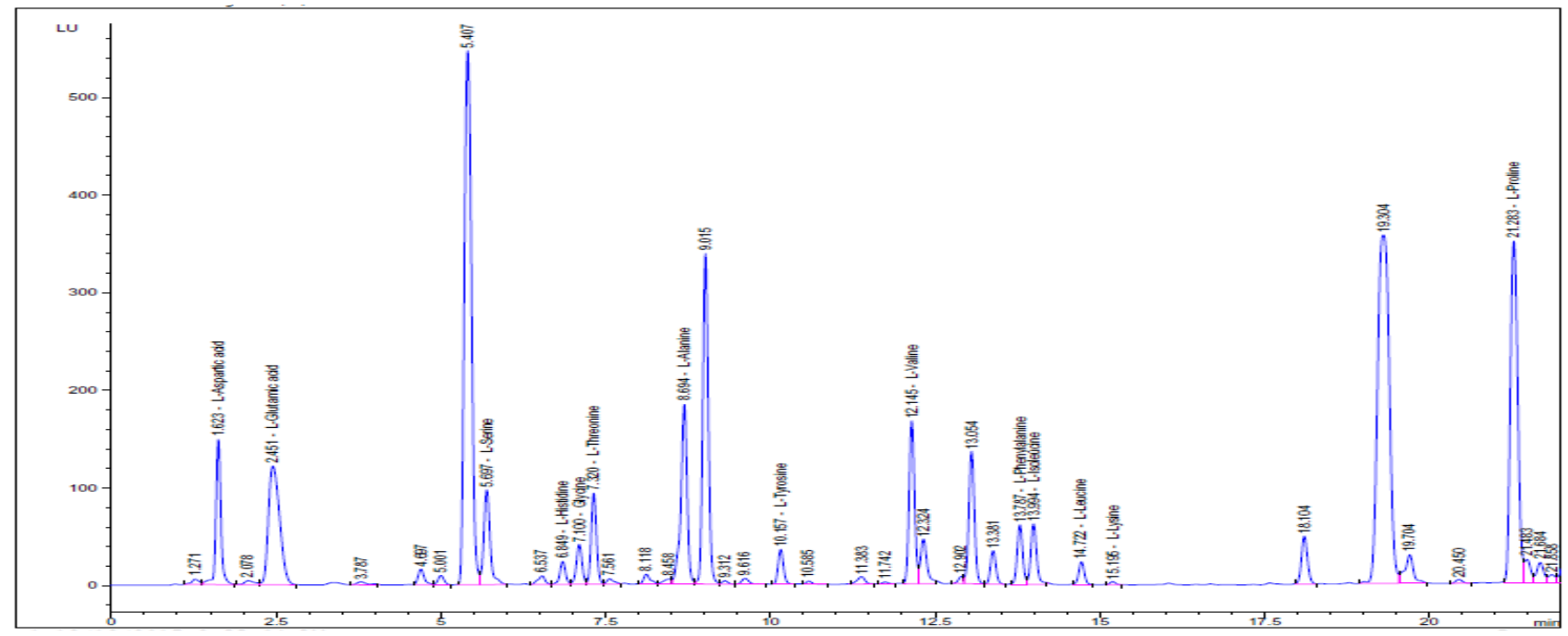

Рис. 1. ВЕРХ-хроматограма, отримана в умовах дослідження вільних амінокислот листя шовковиці білої (зразок 2).

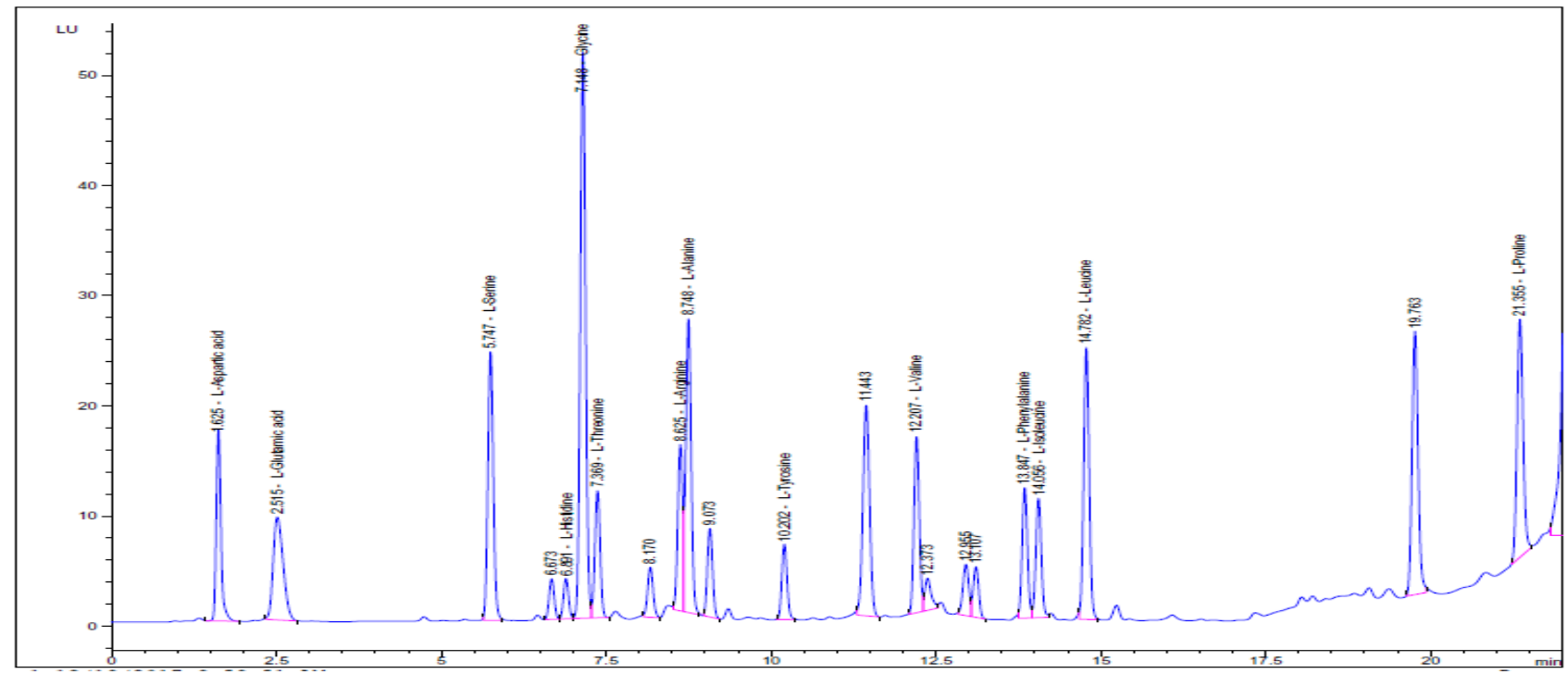

Рис. 2. ВЕРХ-хроматограма, отримана в умовах визначення загального вмісту амінокислот листя шовковиці білої (зразок 5).

У хроматографічних профрілях, отриманих при дослідженні вільних амінокислот зразків 2-5 листя шовковиці білої, було ідентифріковано 14 амінокислот: аспарагінова, глутамінова, серин, гістидин, гліцин, треонін, аланін, тирозин, валін, френілаланін, ізолейцин, лейцин, лізин і пролін; водночас у зразкові 1 не виявлено лізин, який в інших зразках присутній, хоч і в незначній кількості. Результати кількісного визначення вільних амінокислот представлені у таблиці 1 і на рисунку 4.

Усі дослідні зразки сировини є однорідними за складом (рис. 4), а до шести лідерів за вмістом на- лежать сполуки: глутамінова кислота, пролін, аспарагінова кислота, аланін, серин і валін; у першому зразкові - треонін замість аспарагінової кислоти, а в третьому зразкові - гістидин замість серину. Сумарний вміст вільних амінокислот у 1-5 зразках був достатньо однорідний і становив 0,48 \%, 0,70 \%, 0,54 \%, 0,62 \% і 0,49 \% відповідно.

Гідроліз, здійснений у більш жорстких умовах і впродовж 24 год, дав можливість визначити загальний вміст вільних і зв'язаних амінокислот у дослідних зразках сировини (табл. 1). За різницею вмісту було пораховано кількості зв'язаних амінокислот, діаграму

ISSN 2312-0967. Фармацевтичний часопис. 2021. № 1 
Фітохімічні дослідження

Phytochemical researches

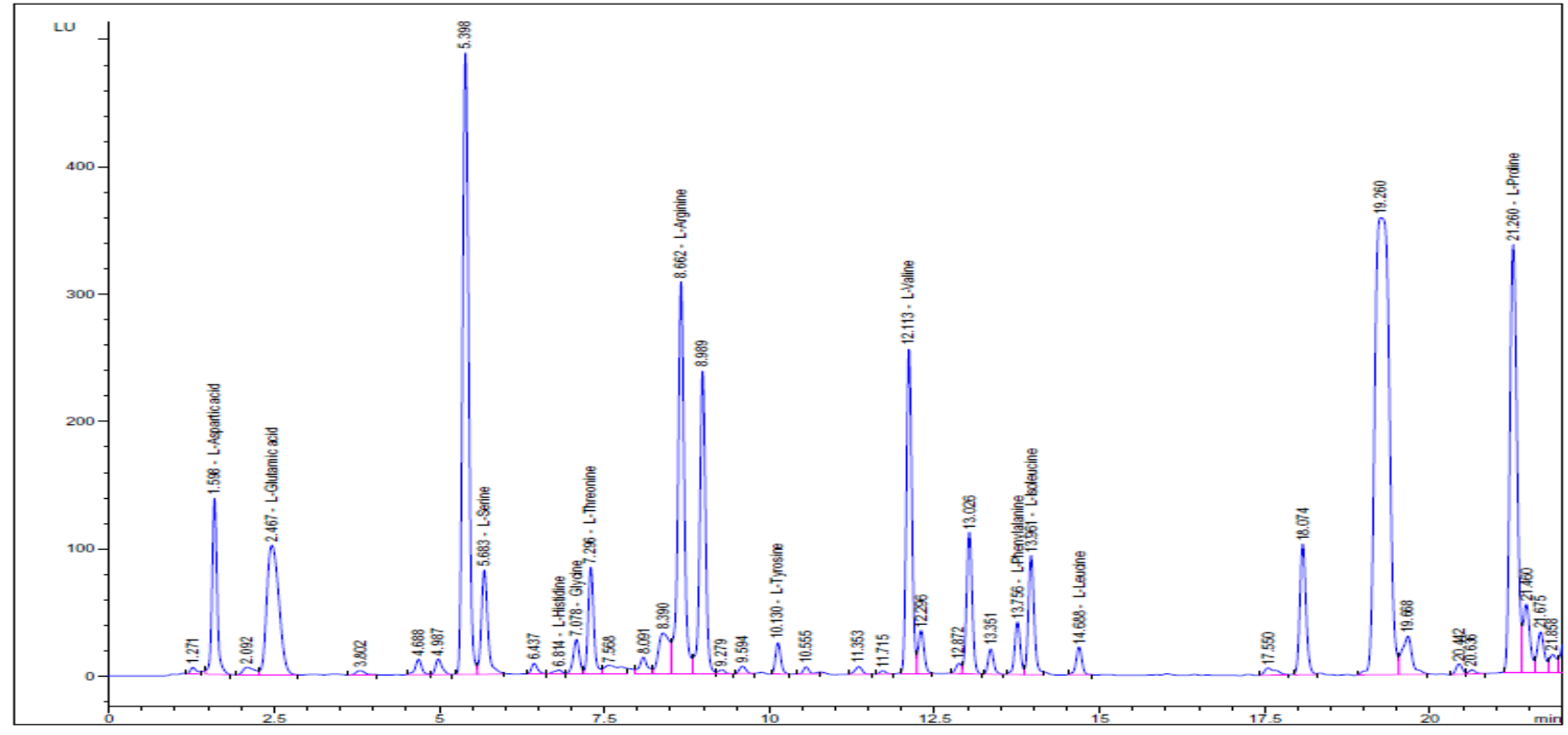

Рис. 3. ВЕРХ-хроматограма, отримана в умовах дослідження вільних амінокислот сухого екстракту листя шовковиці білої.

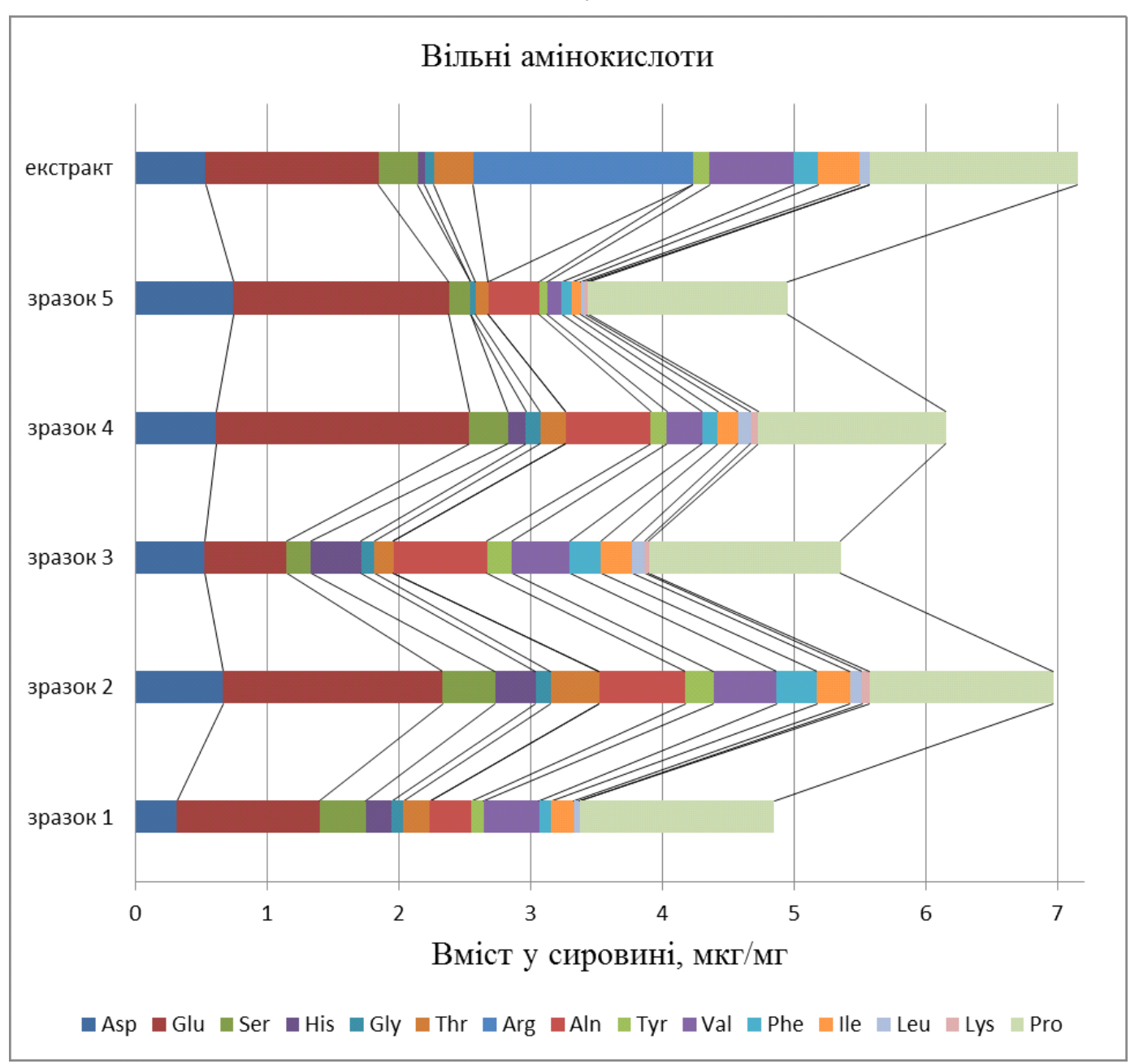

Рис. 4. Діаграма вмісту вільних амінокислот у зразках 1-5 листя шовковиці білої і сухому екстракті на його основі.

ISSN 2312-0967. Pharmaceutical review. 2021. № 1 
Фітохімічні дослідження

Phytochemical researches

Таблиця 1

Вміст амінокислот у листі шовковиці білої та сухому екстракті на його основі за результатами хроматограсрічного визначення

\begin{tabular}{|c|c|c|c|c|c|c|c|c|c|c|c|c|}
\hline \multirow{3}{*}{ Речовина } & \multicolumn{12}{|c|}{ Вміст амінокислот у зразку сировини, мкг/мг } \\
\hline & \multicolumn{6}{|c|}{ вільних } & \multicolumn{6}{|c|}{ вільних і зв'язаних } \\
\hline & 1 & 2 & 3 & 4 & 5 & $\begin{array}{c}\text { екс- } \\
\text { тракт }\end{array}$ & 1 & 2 & 3 & 4 & 5 & $\begin{array}{c}\text { екс- } \\
\text { тракт }\end{array}$ \\
\hline $\begin{array}{l}\text { Аспарагіно- } \\
\text { ва кислота }\end{array}$ & 0,315 & 0,663 & 0,526 & 0,611 & 0,743 & 0,534 & 2,867 & 3,442 & 3,110 & 2,866 & 2,944 & 2,901 \\
\hline $\begin{array}{l}\text { Глутамінова } \\
\text { кислота }\end{array}$ & 1,080 & 1,666 & 0,623 & 1,923 & 1,636 & 1,312 & 4,974 & 5,639 & 4,828 & 5,438 & 5,935 & 2,990 \\
\hline Серин & 0,351 & 0,403 & 0,184 & 0,291 & 0,163 & 0,298 & 2,562 & 2,806 & 2,518 & 2,779 & 3,107 & 0,412 \\
\hline Гістидин & 0,199 & 0,303 & 0,378 & 0,136 & $\mathrm{H}$ & 0,050 & 1,888 & 2,343 & 2,076 & 2,327 & 2,478 & 0,117 \\
\hline Гліцин & 0,087 & 0,116 & 0,101 & 0,111 & 0,040 & 0,072 & 4,573 & 5,321 & 5,012 & 5,545 & 6,758 & 0,429 \\
\hline Треонін & 0,203 & 0,368 & 0,147 & 0,194 & 0,097 & 0,299 & 1,716 & 1,955 & 1,635 & 1,908 & 2,037 & 0,406 \\
\hline Аргінін & $\mathrm{H}$ & $\mathrm{H}$ & $\mathrm{H}$ & $\mathrm{H}$ & $\mathrm{H}$ & 1,666 & 3,835 & 4,382 & 4,119 & 4,532 & 5,215 & 1,979 \\
\hline Аланін & 0,315 & 0,655 & 0,709 & 0,645 & 0,384 & $\mathrm{H}$ & 3,073 & 3,567 & 3,098 & 3,621 & 3,861 & $\mathrm{H}$ \\
\hline Тирозин & 0,090 & 0,214 & 0,190 & 0,123 & 0,061 & 0,125 & 1,605 & 1,849 & 1,459 & 1,765 & 1,908 & 0,189 \\
\hline Валін & 0,422 & 0,477 & 0,436 & 0,264 & 0,109 & 0,639 & 1,725 & 1,900 & 1,501 & 1,843 & 1,966 & 0,811 \\
\hline Метіонін & $\mathrm{H}$ & $\mathrm{H}$ & $\mathrm{H}$ & $\mathrm{H}$ & $\mathrm{H}$ & $\mathrm{H}$ & 1,011 & 0,250 & 0,919 & 1,002 & 1,577 & $\mathrm{H}$ \\
\hline Фенілаланін & 0,093 & 0,309 & 0,238 & 0,118 & 0,080 & 0,185 & 2,517 & 2,982 & 2,355 & 2,855 & 3,146 & 0,322 \\
\hline Ізолейцин & 0,171 & 0,246 & 0,239 & 0,155 & 0,065 & 0,317 & 1,650 & 1,846 & 1,397 & 1,814 & 1,960 & 0,443 \\
\hline Лейцин & 0,042 & 0,092 & 0,096 & 0,096 & 0,030 & 0,076 & 3,988 & 4,526 & 3,728 & 4,567 & 4,923 & 0,207 \\
\hline Лізин & $\mathrm{H}$ & 0,058 & 0,030 & 0,057 & 0,029 & $\mathrm{H}$ & 1,635 & 2,248 & 1,647 & 2,253 & 2,934 & $\mathrm{H}$ \\
\hline Пролін & 1,478 & 1,395 & 1,455 & 1,427 & 1,510 & 1,578 & 1,532 & 1,621 & 1,460 & 1,561 & 1,517 & 8,669 \\
\hline Разом & 4,846 & 6,965 & 5,352 & 6,151 & 4,947 & 7,151 & 41,153 & 46,677 & 40,862 & 46,676 & 52,266 & 19,875 \\
\hline
\end{tabular}

Примітка. н - речовину не виявлено.

розподілу яких у різних зразках представлено на рисунку 5.

Якісний склад зв'язаних амінокислот є однаковим для усіх досліджених зразків сировини - 16 амінокислот, чотирнадцять 3 яких, було ідентифіковано і у вільному стані, і додатково - аргінін та метіонін ідентифріковані тільки у зв'язаному стані. Вміст окремих сполук $є$ також достатньо однорідним як випливає 3 рисунка 5. Порівняння складу вільних і зв'язаних амінокислот приводить до висновку, що аргінін та метіонін перебувають в сировині тільки у зв'язаному стані (табл. 1). До сімки лідерів за вмістом належать: гліцин, глутамінова кислота, аргінін, лейцин, аланін, френілаланін і серин і тільки у зразках 1 та 2 замість серину лідирує кислота аспарагінова. Вміст зв'язаних амінокислот у 5 зразкові (4,73 \%) був вищим (табл. 2) порівняно із зразками сировини вітчизняного походження - 3,55-4,05 \%.

Авторами $[10,13]$ досліджено, серед іншого, склад і загальний вміст амінокислот у листі шовковиці білої, зібраному у Київській області. Ці автори ідентифрікували і кількісно визначили 17 амінокислот, тобто додатково, порівняно із нашими дослідженнями, ідентифрікували цистеїн і визначили його вміст - 0,774 \%, завдяки чому загальний вміст амінокислот для їхнього зразка сировини склав 5,808 \% [13]. Цей результат дещо вищий від отриманих нами для зразків сировини вітчизняного походження $(4,09-4,67)$, що, ймовірно, пов'язано із різними термінами заготівлі сировини та умовами її зростання.

У сухому екстракті листя шовковиці білої, на відміну від сировини, у помітній кількості у вільному стані визначено аргінін - 0,17 \% (табл. 1), а сумарний вміст вільних амінокислот вищий $(0,72 \%)$ від вмісту в зразках сировини (табл. 2). Якісний склад вільних амінокислот відрізняється від складу у зразках сировини присутністю аргініну й відсутністю аланіну й лізину (рис. 4), що пов'язано як із різною розчинністю у спиртових розчинах, так і з процесами, які відбуваються при екстрагуванні, наприклад, гідроліз. Зако-

ISSN 2312-0967. Фармацевтичний часопис. 2021. № 1 


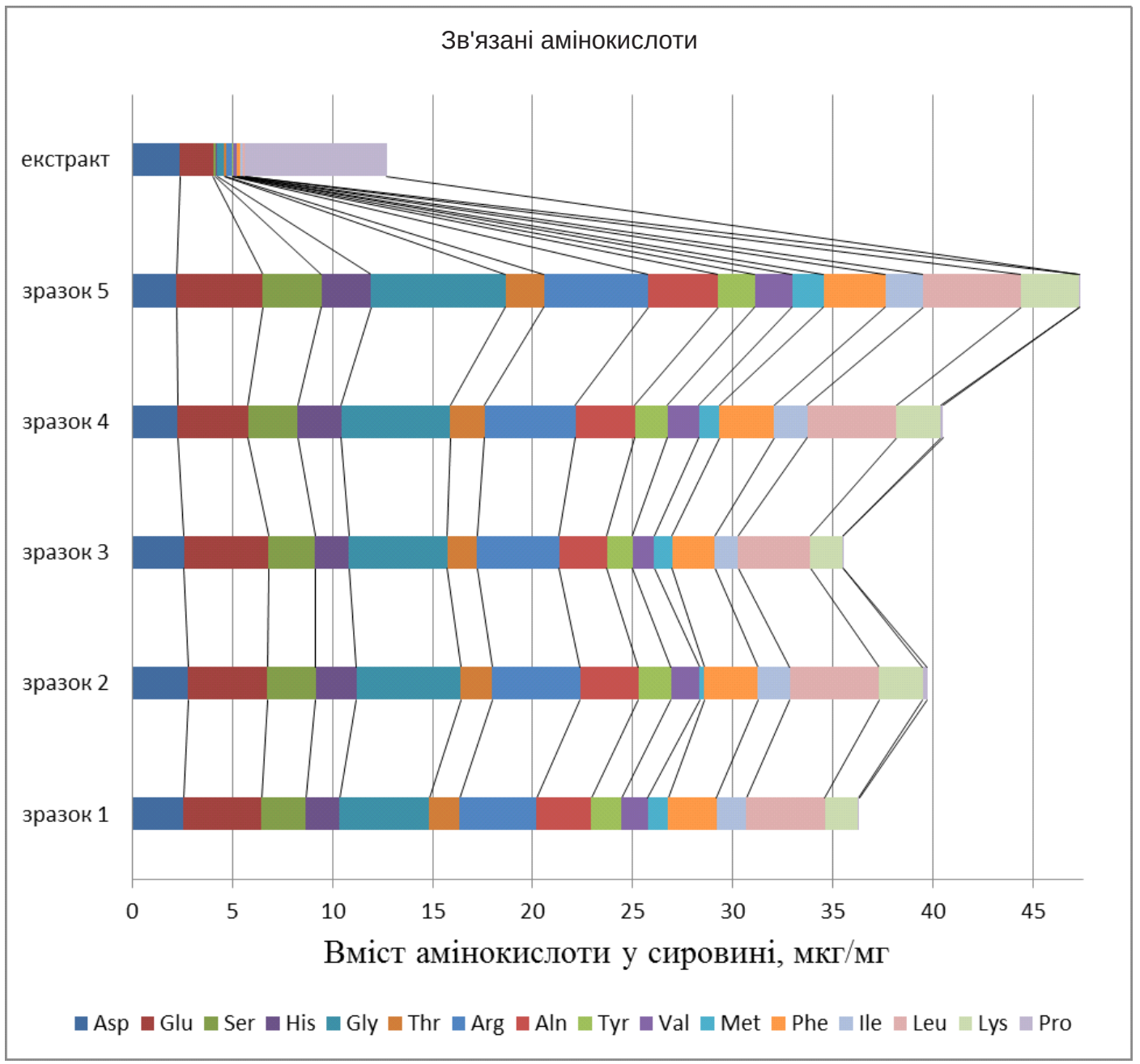

Рис. 5. Діаграма вмісту зв'язаних амінокислот у зразках 1-5 листя шовковиці білої і сухому екстракті на його основі.

\section{Таблиця 2}

Результати хроматографрічного визначення амінокислот у листі шовковиці білої та сухому екстракті на його основі

\begin{tabular}{|c|c|c|c|}
\hline \multirow{2}{*}{ Зразок } & \multicolumn{2}{|c|}{ Вміст, у перерахунку на суху сировину, \% } \\
\cline { 2 - 4 } & вільні & зв'язані & загальний \\
\hline 1 & 0,48 & 3,63 & 4,11 \\
\hline 2 & 0,70 & 3,97 & 4,09 \\
\hline 3 & 0,54 & 3,55 & 4,67 \\
\hline 4 & 0,62 & 4,05 & 5,22 \\
\hline 5 & 0,49 & 4,73 & 1,99 \\
\hline
\end{tabular}

номірно, що вміст зв'язаних амінокислот в екстракті значно нижчий, ніж у сировині, а тому і загальний вміст амінокислот є нижчим, порівняно із сировиною (табл. 2).

У процесі дослідження стабільності, вибору умов зберігання та встановлення термінів придатності си- ровини й екстракту необхідно враховувати лабільність присутніх амінокислот.

Висновки. 1. Методом ВЕРХ вивчено амінокислотні профрілі п'яти зразків листя шовковиці білої. Встановлено, що склад $є$ достатньо однорідним для всіх зразків і включає 16 амінокислот, з яких $7 €$ неза-

ISSN 2312-0967. Pharmaceutical review. 2021. № 1 
мінними: ізолейцин, лейцин, лізин, метіонін, френілаланін, треонін і валін, а також дві частково незамінні - аргінін і гістидин. Загальний вміст амінокислот коливається в межах 4,09-4,67\%.

2. У сухому екстракті листя шовковиці білої визначено вміст 13 амінокислот у вільному стані, 3 яких 5 незамінних - треонін, валін, френілаланін, ізолейцин, лейцин і 2 - частково незамінні: аргінін і гістидин. Вміст вільних амінокислот в екстракті - 0,72 \%, а загальний вміст вільних і зв'язаних амінокислот $1,99 \%$

3. Необхідно враховувати присутність вільних амінокислот і білкових речовин, які є лабільними, при дослідженні стабільності і встановленні терміну придатності сировини і сухого екстракту листя шовковиці білої.

Конфлікт інтересів: відсутній.

Conflicts of interest: the author has no conflict of interest to declare.

\title{
STUDY OF AMINO ACID PROFILE OF WHITE MULBERRY LEAVES RAW MATERIAL AND DRY EXTRACT BASED ON IT
}

\author{
L. V. Vronska \\ I. Horbachevsky Ternopil National Medical University \\ vronska_liudmyla@ukr.net
}

The aim of the work. Study of the amino acid profile of white mulberry leaves raw material and dry extract based on it. Materials and Methods. Four samples of white mulberry leaves raw material were collected in Volyn, Mykolaiv and Ternopil regions, and one sample was purchased as a dietary supplement "Morwa biała" (APTEO NATURA, Poland). Dry extract of white mulberry leaves was obtained from the raw materials of domestic origin by the fractional maceration method, using the ethanol $(80-60 \%, v / v)$. The study of the qualitative and quantitative composition of the white mulberry leaves raw material and its dry extract was carried out by high performance liquid chromatography.

Results and Discussion. Amino acid profiles of the four studied samples of the domestic origin raw material are the same in composition and quite homogeneous in content. The profile of white mulberry leaves contains 14 amino acids in the free state for raw material and 13 - for the its dry extract, of which essential and partially essential are 7 and 2 for raw material and 5 and 2 for the dry extract respectively. The content of amino acids, in the free state, for different samples of raw material ranged from 0.48 to $0.70 \%$ and for dry extract it was $0.72 \%$; in terms of content, the leaders in the raw materials were: glutamic acid, proline, aspartic acid, valine and alanine, while in the extract - arginine, proline, glutamic acid, valine, aspartic acid. The bound amino acids profile for the raw material is represented by 16 compounds, among which the leaders in content were: glycine, leucine, arginine, glutamic and aspartic acids, alanine and phenylalanine. The total content of free and bound amino acids (4.09-4.67\%) for the samples of domestic origin raw materials was slightly inferior to total content of them for the sample of dietary supplement purchased at the pharmacy $-5.22 \%$.

Conclusions. 1. The amino acid profiles of the five samples of white mulberry leaves were studied by HPLC. It is established that the composition is quite homogeneous, and the total content ranges from 4.09 to $4.67 \%$.

2. The 13 amino acids were identified in the free state, of which 5 are essential and 2 are partially essential, in the dry extract of white mulberry leaves. There were determined the content of free amino acids in the extract $-0.72 \%$ and the total content of free and bound amino acids $-1.99 \%$.

3. The presence of free and bound amino acids must be taken into account when examining the stability, storage conditions and shelf life of raw material and dry extract of white mulberry leaves.

Key words: white mulberry leaves; dry extract; amino acids.

\section{ИЗУЧЕНИЕ АМИНОКИСЛОТНОГО ПРОФИЛЯ СЫРЬЯ ЛИСТЬЕВ ШЕЛКОВИЦЫ БЕЛОЙ И СУХОГО ЭКСТРАКТА НА ИХ ОСНОВЕ}

\section{Л. В. Вронска}

\section{Тернопольский национальный медицинский университет имени И. Я. Горбачевского Мз Украины} vronska_liudmyla@ukr.net

Цель работы. Изучение аминокислотного профиля листьев шелковицы белой и сухого экстракта на его основе. Материалы и методы. Четыре образца сырья листьев шелковицы белой были собраны в Волынской, Николаевской и Тернопольской областях, один образец был приобретен как диетическая добавка «Morwa biała» (APTEO NATURA, Польша). Сухой экстракт листьев шелковицы белой получали из сырья отечественного происхождения

ISSN 2312-0967. Фармацевтичний часопис. 2021. № 1 
методом дробной мацерации, применяя этанол (80-60 \% об/об). Исследование качественного и количественного состава сырья листьев шелковицы белой и экстракта на его основе осуществляли методом высокоэффективной жидкостной хроматографии.

Результаты и обсуждение. Аминокислотные профили четырех исследованных образцов сырья отечественного происхождения одинаковы по составу и достаточно однородны по содержанию. Профиль листьев шелковицы белой содержит 14 аминокислот в свободном состоянии для сырья и 13 - для сухого экстракта, из которых незаменимых и частично незаменимых - 7 и 2 для сырья и 5 и 2 - для экстракта. Определено содержание аминокислот в свободном состоянии для различных образцов сырья - 0,48-0,70 \% и для сухого экстракта - 0,72 \%; лидерами по содержанию в сырье были: глутаминовая кислота, пролин, аспарагиновая кислота, валин и аланин, тогда как в экстракте - аргинин, пролин, глутаминовая кислота, валин, аспарагиновая кислота. Профиль связанных аминокислот в сырье представлен 16 соединениями, среди которых лидерами по содержанию были: глицин, лейцин, аргинин, глутаминовая и аспарагиновая кислоты, аланин и фенилаланин. Общее содержание свободных и связанных аминокислот в образцах сырья отечественного происхождения (4,09-4,67 \%) несколько уступал их содержанию в аптечном образце диетической добавки - 5,22 \%.

Выводы. 1. Методом ВЭЖХ изучено аминокислотные профили пяти образцов листьев шелковицы белой. Установлено, что состав достаточно однороден, а общее содержание колеблется в пределах 4,09-4,67 \%.

2. 13 аминокислот, находящихся в свободном состоянии, из которых 5 - незаменимые и 2 - частично незаменимые, идентифицированы в сухом экстракте листьев шелковицы белой. В сухом экстракте определено содержание свободных аминокислот - 0,72 \% и общее содержание свободных и связанных аминокислот - 1,99\%.

3. При исследовании стабильности, установлении условий хранения и срока годности сырья и сухого экстракта листьев шелковицы белой необходимо учитывать присутствие свободных и связанных аминокислот.

Ключевые слова: листья шелковицы белой; сухой экстракт; аминокислоты.

\section{Список бібліографрічних посилань}

1. Diminishes visceral adiposity, insulin resistance, behavioral alterations via regulation of gene expression of leptin, resistin and adiponectin in rats fed a highcholesterol diet. F. M. Metwally, H. Rashad, A. A. Mahmoud, L. Morus alba. Physiology \& Behavior. 2019. Vol. 201. P. 1-11.

2. Antioxidant flavan derivatives from the leaves of Morus alba. H.-R. Zhang, M. Li, M-M. Wang et al. Phytochemistry Letters. 2019. Vol. 29. P. 84-90.

3. Antioxidant activities and polyphenol content of Morus alba leaf extracts collected from varying regions. Dong-Seon Kim, Young Min Kang, Wen Yi Jin et al. Biomedical Reports. 2014. Vol. 2. P. 675-680.

4. Grajek K., Wawro A., Pieprzyk-Kokocha D. Bioactivity of Morus Alba L. extracts - an overview. Int. J. of Pharm. Sci. and Res. 2015. Vol. 6, Iss. 8. P. 3110-3122.

5. Simin Tian, Mingmin Tang, Baosheng Zhao. Current anti-diabetes mechanisms and clinical trials using Morus alba L. J. of Traditional Chinese Med. Sci. 2016. Vol. 3. P. 3-8.

6. Chemical constituents of Morus alba L. and their inhibitory effect on 3T3-L1 preadipocyte proliferation and differentiation. Y. Yang, X. Yang, B. Xu et al. Fitoterapia. 2014. Vol. 98, Iss. 10. P. 222-227.

7. Morus Alba Linn: A Phytopharmacological review. Bandna Devi, Neha Sharma, Dinesh Kumar et al. Int. J. of Pharmacy and Pharm. Sci. 2013. Vol. 5, suppl. 2. P. 14-18.

8. Metabolic effects of mulberry leaves: exploring potential benefits in type 2 diabetes and hyperuricemia. A. Hu- nyadi, E. Liktor-Busa, A. Marki et al. Evidence-Based Complementary and Alternative Medicine. Vol. 2013, Article ID 948627. $10 \mathrm{p}$.

9. Zhong L., Furne J. K., Levitt M. D. An extract of black, green, and mulberry teas causes malabsorption of carbohydrate but not of triacylglycerol in healthy volunteers. Amer. J. Clin. Nutr. 2006. Vol. 84. P. 551-555.

10. Цуркан О. О., Ковальчук Т. В., Гергель О.В.Вивчення біологічно активних речовин надземної частини шовковиці білої (Morus Alba L.) і шовковиці чорної (Morus Nigra L.). Фарм. журнал. 2011. № 6. C. 72-78.

11. Study of biologically active substances of White Mulberry leaves and their extracts. L. Vronska, A. Demyd, A. Dub et al. Plant - the source of research material: $5^{\text {th }}$ International Conference and Workshop, 21 - 24. 06. 2017 r.: book of abstracts. Lublin, 2015. P. 167.

12. Вплив концентрації етанолу в екстрагенті на фрлавоноїдний профріль витягу із листя шовковиці білої і його цукрознижувальну дію / Л. В. Вронська, А. І. Дуб, А. Є. Демид, та ін. Фармац. часопис. 2020. № 1. С. 5-13.

13. Вивчення амінокислотного складу листя та кори шовковиці білої (Morus Alba L.) і шовковиці чорної (Morus Nigra L.) / О. О. Цуркан, Т. В. Ковальчук, О.В.Гергель. Фітотерапія. 2010. № 3. С. 56-58.

14. Rapid, accurate, sensitive, and reproducible HPLC analysis of amino acid. Amino acid analysis using Zorbax Eclipse-AAA columns and the Agilent 1100 HPLC. J. W. Henderson, R. D. Ricker, B. A. Bidlingmeyer et al. Agilent Technical Note. 1999. No. 5980. P. 1193E.

ISSN 2312-0967. Pharmaceutical review. 2021. № 1 


\section{References}

1. Metwally FM, Rashad H, Mahmoud AA. Morus alba L. Diminishes visceral adiposity, insulin resistance, behavioral alterations via regulation of gene expression of leptin, resistin and adiponectin in rats fed a highcholesterol diet. Physiology \& Behavior. 2019;201: 1-11. DOI:10.1016/j.physbeh.2018.12.010.

2. Zhang $H-R$, Li M, Wang $M-M$, Wang $X-N$, Shen $T$, Wang S-Q, Ren D-M. Antioxidant flavan derivatives from the leaves of Morus alba. Phytochemistry Letters. 2019;29: 84-90. DOI:10.1016/j.phytol.2018.11.002.

3. Dong-Seon Kim, Young Min Kang, Wen Yi Jin, Yoon-Young Sung, Goya Choi, Ho Kyoung Kim. Antioxidant activities and polyphenol content of Morus alba leaf extracts collected from varying regions. Biomedical Reports, 2014;2: 675-80. DOI: 10.3892/br.2014.294.

4. Grajek K, Wawro A, Pieprzyk-Kokocha D. Bioactivity of Morus Alba L. extracts - an overview. Intern J Pharm Sci and Res. 2015;6(8): 3110-22.

5. Simin Tian, Mingmin Tang, Baosheng Zhao. Current anti-diabetes mechanisms and clinical trials using Morus alba L. J. of Traditional Chinese Med Sci. 2016;3: 3-8. DOI: 10.1016/J.JTCMS.2016.04.001.

6. Yang $Y$, Yang X, Xu B, Zeng G, Tan J, He X, Changping $H$, Zhou Y. Chemical constituents of Morus alba L. and their inhibitory effect on 3T3-L1 preadipocyte proliferation and differentiation. Fitoterapia. 2014;98(10): 222-227. DOI: 10.1016/j.fitote.2014.08.010.

7. Bandna Devi, Neha Sharma, Dinesh Kumar, Kamal Jeet. Morus Alba Linn: A Phytopharmacological review. Int J Pharmacy and Pharm Sci. 2013;5(2): 14-8.

8. Hunyadi A, Liktor-Busa E, Marki A, Martins A, Jedlinszki N, Hsieh TJ, Báthori M, Hohmann J, Zupko I. Metabolic effects of Mulberry leaves: Exploring potential benefits in type 2 diabetes and hyperuricemia. Evidence-Based
Complementary and Alternative Medicine. 2013;ID 948627. DOI: 10.1155/2013/948627.

9. Zhong L, Furne JK, Levitt MD. An extract of black, green, and mulberry teas causes malabsorption of carbohydrate but not of triacylglycerol in healthy volunteers. Amer J Clin Nutr. 2006;84: 551-5. DOI: 10.1093/ ajcn/84.3.551

10. Tsurkan OO, Kovalchuk TV, Herhel OV. Study of biologically active substances of the aboveground part of white mulberry (Morus Alba L.) and black mulberry (Morus Nigra L.). Farm zhurn. 2011;6: 72-78. Ukrainian.

11. Vronska L, Demyd A, Dub A, Hroshoviy T, Klishch I. Study of biologically active substances of White Mulberry leaves and their extracts. In: Anna Bogucka-Kocka, Grazyna Szymczak, Janusz Kocki, Ireneusz Sowa editors. Plant - the source of research material: Proceedings of the $5^{\text {th }}$ International Conference and Workshop, 2017 Jun 21 - 24. Lublin: POLIHIMNIA; 2015.

12. Vronska LV, Dub Al, Demyd AYe, Hroshovyi TA, Klishch IM. The influence of the ethanol content in the extractant on flavonoids profile of the nulberry white leaves extracts and its sugar-lowering effect. Farm chasop. 2020;1: 5-13. DOI: 10.11603/23120967.2020.1.10983. Ukrainian.

13. Tsurkan OO, Kovalchuk TV, Gergel OV. Study of amino acid composition of leaves and bark of white mulberry (Morus Alba L.) and black mulberry (Morus Nigra L.). Fitoterap. 2010;3: 56-8. Ukrainian.

14. Henderson JW, Ricker RD, Bidlingmeyer BA, Woodward C. Rapid, accurate, sensitive, and reproducible HPLC analysis of amino acid. Amino acid Analysis using Zorbax Eclipse-AAA columns and the Agilent 1100 HPLC. Agilent Technical Note. 1999;5980:1193E.

\section{Відомості про автора}

Вронська Л. В. - канд. хім. наук, доцент кафедри фрармації, Тернопільський національний медичний університет імені І. Я. Горбачевського МО3 України, Тернопіль, Україна. E-mail: vronska_liudmyla@ukr.net, ORCID 0000-00027223-6966.

\section{Information about the author}

Vronska L. V. - PhD (Chemistry), Associate Professor of the Pharmacy Department, I. Horbachevsky Ternopil National Medical University, Ternopil, Ukraine. E-mail: vronska_liudmyla@ukr.net, ORCID 0000-0002-7223-6966. 